\title{
Svenska kyrkan efter millennieskiftet
}

\author{
JØRGEN STRAARUP
}

\begin{abstract}
ENGLISH ABSTRACT: Since the year 2000, the Church of Sweden is no longer a function within the Swedish state. It has become a free denomination which actualizes several borderland changes in the Swedish model of religion. The dissolution of the relationship with the state has been discussed and prepared for many years, and it became a reality at the turn of the millennium. The need for a defined relationship with the state or an interface, however, has not diminished, since the Church of Sweden is still the largest popular movement in the country. This change in relation has lead to an intensified cooperation between the Church of Sweden and other churches and denominations.
\end{abstract}

SVENSK ABSTRACT: Sedan år 2000 är Svenska kyrkan inte längre en funktion i svenska staten, utan ett fritt trossamfund. Denna relationsförändring aktualiserar en rad nya gränssnitt $i$ den svenska religionsmodellen. Upplösningen av sammanhanget med staten har diskuterats och förberetts under många år och förverkligats $i$ samband med millennieskiftet. Behovet av definierad relation till statsmakten, ett gränssnitt, minskade emellertid inte, eftersom Svenska kyrkan även efter nyårsmorgon 2000 var landets största folkrörelse. Relationsförändringen ledde till ett intensifierat samarbete med andra kyrkor och samfund.

KEYWORDS: State church; millennium; denomination; burial; historic building

Nyårsnatten 1999 - 2000 klipps, efter mer än fyra århundraden av samexistens, banden mellan svenska staten och den evangelisk-lutherska kyrkan, kallad Svenska kyrkan. Denna separation innebär att det uppkommit nya gränssnitt mellan staten, majoritetskyrkan Svenska kyrkan och de andra trossamfunden i den svenska religionsmodellen. Artikeln beskriver de relationsförändringar som åtskillnaden mellan stat och kyrka leder till. Processen som leder fram till denna så kallade skilsmässa är lång. Stat och kyrka är i svensk lagstiftning två storheter som ofta går in i varandra, vilket gör en skilsmässa komplicerad. En hög jurist, hovrättspresidenten Carl-Axel 
Petri, är sysselsatt ett antal år med att bena upp de många och intrikata bindningarna mellan statsmakt och statskyrka och med att föreslå förändrad lagstiftning som ersättning (ERK-utredningen 1992). Eftersom Svenska kyrkan haft status som en av tre typer av geografiskt definierade kommuner (landsting [amtskommune], kommun [kommune], församling [sogn]) har den lokalt kunnat besluta om beskattning av sina invånare. Också för denna beskattningsrätt behöver man hitta nya former.

En ny ordning beslutas i kyrkomöte och riksdag de två sista åren före millennieskiftet, och nyårsdagen 2000 träder den nya ordningen i kraft. Merparten av den statliga normgivningen av kyrkans angelägenheter är då borta. Det juridiska regelverk som kvarstår är (a) en särskild, minimal, lag om Svenska kyrkan, och (b) en generell lag om trossamfund. Tidigare statlig normering av svenskkyrkliga detaljspörsmål överförs till en Kyrkoordning, som den svenska synoden 'Kyrkomötet' är beslutsorgan för (Kyrkomötet 1999).

En effekt av relationsförändringen är att Sveriges riksdag inte längre behöver ta ställning till kyrkliga böcker som t.ex. psalmbok och evangeliebok, en roll som blivit obekväm för en ökande andel av Riksdagens ledamöter. Dessutom upphör statsmaktens inflytande över tillsättningen av biskopar. Kyrkogeografisk indelning (stift, kontrakt [provsti], församling) blir en intern kyrklig angelägenhet och indelningens värde för icke-kyrkligt bruk ifrågasätts. Statens statistikmyndighet vill gärna bevara församlingsindelningen som officiell indelning, medan skattemyndigheten inte längre har någon användning av den.

Det tar lång tid att vända en oljetanker, sägs det. Det har också tagit lång tid att vända Svenska kyrkan. Under i stort sett hela andra halvan av 1900-talet har utredning följt på utredning för att undersöka möjligheterna att upplösa banden mellan stat och kyrka, och flera gånger har utredningsförslag hyst viss framgång i Riksdagen för att sedan bli nedröstade i Kyrkomötet. Det skulle leda för långt att gå in på de politiska processer som resulterade i att Kyrkomötet äntligen - ett par år före millennieskiftet - gick med på att lösa bandet till statsmakten, men man kan åtminstone säga att det har handlat om en kombination av sak- och partipolitik.

\section{Nya gränssnit i den svenska religionsmodellen}

Från mitten av 1990-talet till 2014 har relationen mellan svenska staten och organiserad religion genomgått en rad förändringar. Den viktigaste av dessa förändringar är den som resulterar i att Svenska kyrkan upphör med att vara statens kyrka. En del av staten (Svenska kyrkan) bryts ut och övergår till gruppen av religiösa organisationer (kyrkor, samfund). Gamla gränssnitt internt inom staten (sådant som handlar om intern reglering av Svenska kyrkans status och verksamhet) ersättas med nya gränssnitt, som ska säkra smidig funktionalitet efter utbrytningen. Dessa nya gränssnitt ska dock samtidigt anpassas efter andra kyrkor och samfund, i och med att staten endast med svårighet kan ge försteg eller privilegier för någon kyrka eller något 
samfund. Den stora gränssnittsförändringen drar alltså med sig att en rad andra gränssnitt kan behöva justeras.

\section{Gränssnittsförändringens del 1: Svenska kyrkan bryts ur svenska staten}

Svenska kyrkan upphör att vara en funktion inom statsmakten. Sambandet mellan stat och kyrka upplöses. Svenska kyrkans fortsatta existens som kyrka nödvändiggör att staten klargör sin ställning till kyrkan. Även efter relationsförändringen består en relation mellan stat och kyrka, men den är annorlunda än före millennieskiftet. Denna nya relation ger ett nytt gränssnitt. Efter förhandlingar definieras det nya gränssnittet juridiskt. Staten fastlägger genom en särskild lag vissa centrala förhållanden inom Svenska kyrkan. I Lag (1998: 1591) om Svenska kyrkan är den viktigaste paragrafen förmodligen den som definierar kyrkan, dess form och dess uppgift, § 2:

Svenska kyrkan är en öppen folkkyrka, som i samverkan mellan en demokratisk orga-

nisation och kyrkans ämbete bedriver en rikstäckande verksamhet.

“Öppen folkkyrka”, “demokratisk organisation”, "rikstäckande verksamhet” är de tre nyckelorden här. De anger en tydlig kontinuitet med statskyrkan och fungerar dessutom som statsmaktens försäkring mot att olika slag av teologisk inspiration oväntat förvandlar kyrkan till något annat än det som man är van att se.

Någon total åtskillnad mellan staten och Svenska kyrkan är det inte frågan om. Staten definierar med en särskild lag delar av den tidigare statskyrkans interna angelägenheter, men lämnar åt andra trossamfund att själva definiera sin form och uppgift. Inom Svenska kyrkan har röster höjts om kyrkans nya fångenskap i de framförhandlade beskrivande termerna: "öppen folkkyrka", "demokratisk organisation", "rikstäckande verksamhet". Kyrkan ska enligt lagen vara demokratisk, vilket innebär att dess beslutsstruktur ska bygga på allmänna val bland medlemmarna; den ska vara en öppen folkkyrka (vilket få har vågat sig på att definiera) och rikstäckande, vilket innebär att kyrkan ska vara representerad med gudstjänster och annan religiös verksamhet överallt i riket. Inga andra trossamfund har sådana krav på sig. Svenska kyrkans frihet är med andra ord kringskuren, medan andra trossamfund har bevarat sin frihet från den typen av gränsdragningar.

I samband med relationsförändringen blir 'kyrkoskatt' i stället 'kyrkoavgift'. De jure förhåller det sig i Sverige så att endast 'tvångssamfällighet', dvs. ett sammanhang en individ inte kan lämna, kan kräva skatt. Skatt kan efter relationsförändringen endast stat, landsting och kommun kräva. Trossamfund och föreningar är inte tvångssamfälligheter men kan för medlemskap kräva en avgift. Uppbördssystemet [opkrævningssystemet] för skatterna finns emellertid på plats, och statsmakten erbjuder sig att fortsätta dra in avgifterna, förutsatt att kyrkan själv håller reda på vilka församlingar som har rätt till hur mycket avgiftspengar. Svenska kyrkan tackar 'ja', och medlemsavgiften kommer därmed att beräknas som procent av den skattepliktiga inkomsten, i likhet med kyrkoskatten före relationsförändringen. 
Att ge Svenska kyrkan en möjlighet att få in sina medlemsavgifter på detta smidiga sätt skulle kunna ses som ett exempel på att staten behandlar olika trossamfund olika, vilket i sin tur skulle strida mot statens liberala ambition att inte göra skillnad på trossamfund. Möjlighet att få in medlemsavgifter över skattsedeln utsträcks därför att också gälla andra registrerade trossamfund. Inte alla trossamfund har valt att acceptera den lösningen för uppbörd av medlemsavgifterna. Några av de mest tydligt föreningsorienterade trossamfunden har gjort det, för det mesta trossamfund som har funnits länge i landet och som har en tydlig föreningsstruktur. Immigrantsamfund med folkkyrkokaraktär har svårigheter att tillämpa den modellen. Det senare gäller också för islamiska samarbetsorgan och -råd.

Begravningsväsendet - ett specialfall

Eftersom kyrkogårdarna i relationsförändringen blir kyrkans egendom, inte statens, uppkommer ett civilt problem: begravningsorganisationen riskerar att hamna mellan stolar. Problemet löses på så sätt att kyrkan, som är ägare till kyrkogårdarna/ begravningsplatserna, övertar ansvaret för begravningsväsendet. Svenska kyrkan blir enligt Begravningslag (1990: 1144) med ändringar t o m SFS 1999:1268 statsmaktens entreprenör vad gäller begravningsverksamhet.

På ett principiellt plan behöver detta inte vara ett belägg för att åtskillnaden mellan stat och kyrka är ofullständig. Ordningen kan tolkas som en parallell till andra typer av outsourcing, det vill säga funktionsöverlåtelse från offentlig sektor (stat, landsting, kommun) till ett privat företag eller en privat organisation. Det finns sjukhus som drivs privat, privata vaktbolag kompletterar polisen i vissa lägen, utbildningsdepartementet låter ett privat företag sköta den granskning av individuella meriter som leder fram till att lärare kan erhålla en 'lärarlegitimation', etc. Exemplen på outsourcing av offentlig verksamhet är legio.

En praktisk lösning, kan tyckas. Men samtidigt en lösning som aktualiserar en religionsfrihetsproblematik. En ofta sedd uppdelning av religionsfrihet pekar på en positiv och en negativ religionsfrihet. Med dessa termer avses ingen kvalitativ bedömning av religionsfriheten, utan en karakteristik av två olika slag av frihet, frihet 'till' och frihet 'från'. Enligt den positiva religionsfrihetsidéen har varje människa rätt att själv välja religiös övertygelse och eventuellt byta till en annan. Enligt den negativa religionsfrihetsidén har varje människa också rätt att slippa påtvingad religionsutövning. Ingen ska bli tvingad att delta i religionsutövning mot sin vilja (Roth 2012).

Frågan är om den påtvingade kontakten med Svenska kyrkan i begravningsärenden är i strid med religionsfrihetsnormen. Den negativa religionsfriheten (alltså frihet 'från') har tidigare varit omdiskuterad, t.ex. i samband med att folkbokföringen år 1991 övergick från kyrklig till statlig regi, och den problematiken visar sig också här. En evangelisk-luthersk kyrka har fått ansvaret för begravningsplatser för alla, oavsett religiös tillhörighet. Andra trosbekännare, agnostiker och ateister måste alltså i samband med närståendes död ha att göra med en konfessionellt organiserad upp- 
dragstagare, som inom ramen för lagstiftningen ska tillgodose specifika önskemål från andra trossamfund och deras medlemmar, önskemål om gravar, kremation och gravstenar.

Ceremonielet eller högtiden i samband med gravsättningen ingår inte i Svenska kyrkans statliga uppdrag. Hur begravningsgudstjänst, minnesstund eller liknande ska anordnas är de efterlevandes uppdrag att organisera. Merparten (knappt åtta av tio i 2012) av de avlidna begravs efter begravningsgudstjänst i Svenska kyrkans ordning, men andra trossamfunds präster eller representanter kan hålla begravningsceremoni, liksom det finns möjlighet att anordna en icke-religiös, civil begravningshögtid, eller att avstå från en högtid överhuvudtaget (Svenska kyrkan 2014a).

En faktor som sedan millennieskiftet kommit att sätta denna ömtåliga sak på sin spets är att vissa församlingar tillhörande Svenska kyrkan valt att bilda civila begravningsbyråer i företagsform. Denna utveckling har lett till en diskussion om konkurrensförvridning. Samma kyrka som har ett myndighetsuppdrag konkurrerar alltså på den fria marknaden för begravningsentreprenörer [bedemænd], med det stöd som lång erfarenhet av att möta efterlevande och anordna begravningsgudstjänster ger. Kan det vara rätt? En kyrklig utredning som tillsatts för att undersöka om det är i överensstämmelse med kyrkans uppdrag att bilda det slaget av näringsverksamhet kommer fram till att det är i sin ordning. Om verksamheten håller sig inom församlingens geografiska gräns, och därmed står under kyrkoherdens ansvar och biskopens tillsyn, är det möjligt att se näringsverksamhet som en del av kyrkans diakonala uppdrag (Eckerdal 2009).

Vad som eventuellt varit tänkt att bli ett Alexanderhugg mot den gordiska knut, som förenat svenska staten och Svenska kyrkan blir i praktiken ett icke särskilt rent snitt. Resultatet blir inte två oberoende storheter som tillsammans definierar det gränssnitt de önskar med varandra. Statsmakten tar sig friheten att definiera kyrkans form och funktion (vilket strider mot den teologiska idén om kyrkans evangeliska frihet), och kyrkan hittar sätt att ge sig in på områden där statsmakten (förmodligen) inte föreställt sig att kyrkan ska gå in.

Implementering

Svenska kyrkan bryts ut ur svenska staten, men har kommit igenom relationsförändringsprocessen med gott förhandlingsresultat. Den kyrkliga egendomen (kyrkor, andra byggnader, skog, mark och finansiella tillgångar) har inte ifrågasatts. Ett möjligt argument från statlig sida för att staten skulle överta denna egendom, nämligen att dessa tillgångar finansierats med olika slag av offentliga medel, har inte vunnit gehör.

Om vägen fram till det formella beslutet och det formella skiljandet varit lång är vägen till förverkligande kort. De viktigaste lagändringarna och förslaget till Kyrkoordning blir klara under 1998, och de administrativa och legala ändringar som skil- 
jandet innebär är verksamma från den 1:a januari 2000. Vad som däremot tar tid är den mentala omsvängningen för kyrkans personal. Den person som under hela sin yrkeskarriär i Svenska kyrkan varit van att i någon mån representera statsmakten har ett långt kliv till att enbart representera ett trossamfund utan staten i ryggen.

Strävan efter kontinuitet med situationen före millennieskiftet har inte enbart varit en angelägenhet för personalen efter år 2000. Det har också varit en angelägenhet för den kärna av kyrkliga ledare och centrala administratörer som har varit arkitekter för förändringen (Edqvist 2000). Trots de planerade formella skillnaderna har deras ambition varit att kyrkan år 2000 skulle se ut som och upplevas som samma kyrka som år 1995. Denna ambition hos utredare och förändringsarkitekter kan sägas ha blivit förverkligad. För anställda och medarbetare tycks millennieskiftet inte ha inneburit en större skillnad.

I retrospekt kan det konstateras att det på ganska få år har inträffat en terminologisk förändring som sammanhänger med kyrkans nya status som ett trossamfund bland andra. Under sista delen av 1900-talet värjde sig officiella representanter för Svenska kyrkan mot att använda beteckningen 'medlemmar' om dem som hörde till kyrkan. Medlemmar, sades det, hörde hemma i föreningslivet, och i de delar av kristenheten som hade föreningsstruktur, dvs. i praktiken de fria kyrkorna och samfunden. Den term som rekommenderades i stället var 'kyrkotillhöriga', dvs. 'de som hör till kyrkan', en term som riktar tankarna mot en kyrka som omfattar hela befolkningen. I takt med att andelen av befolkningen som tillhörde Svenska kyrkan minskade blev det aktuellt att - trots motståndet mot att använda termen 'medlem' - införa en rad regleringar med syfte att tydliggöra vem som tillhörde och vem som inte tillhörde kyrkan, dvs. som de facto var medlemmar:

(a) En bestämmelse från 1990-talet ledde till att kyrkotillhörighet från och med år 1996 endast kunde förvärvas genom dop (före den bestämmelsen hade det räckt att en av föräldrarna var kyrkotillhörig).

(b) I den nationella kyrkostatistiken skedde under 1990-talet en gradvis förändring. Nyckeltal för den kyrkliga verksamheten relaterades allt mer till antalet kyrkotillhöriga i stället för till invånarna. Som exempel kan nämnas att där uppgifter om t.ex. konfirmation tidigare relaterats till en hel ungdomsårskull, började man i stället relatera sig till antalet kyrkotillhöriga i årskullen. I beskrivning av konfirmationsfrekvensen byttes sålunda nämnaren ut; 'x procent av 15-åringarna har konfirmerats' blev i stället 'z procent av de kyrkotillhöriga 15-åringarna har konfirmerats' .

(c) Allt klarare reglere började utfärdas för icke-kyrkotillhörigas möjligheter att låta sig betjänas av kyrkan, ofta med tydliga prislistor, medan de kyrkotillhöriga hade och har gratis tillgång till vigslar och begravningsgudstjänster. Bit för bit kröp medlemsbegreppet in i kyrkans självmedvetande.

Den processen kan sägas vara slutförd nu en bit in på 2000-talet, då få använder det gamla favoritbegreppet 'kyrkotillhörig'. 


\section{Gränssnittsförändringens del 2: Svenska kyrkan blir ett trossamfund bland andra}

Det faktum att Svenska kyrkan från att ha varit statens kyrka blir en kyrka eller ett samfund bland många andra leder till att staten definierar en ny typ av rättssubjekt, nämligen trossamfundet. Det sker i en generell lag som reglerar hur trossamfund ska förstås.

Svenska kyrkans nya ställning och det nya gränssnittet mellan staten och Svenska kyrkan aktualiserar statens relation till andra kyrkor och samfund. När gruppen av kyrkor och samfund inte enbart omfattar ett antal relativt små organisationer, utan också en organisation som har merparten av Sveriges befolkning som medlemmar (67,5 procent i 2012) kan gränssnittet mellan staten och dessa kyrkor och samfund behöva revideras (Svenska kyrkan 2014a). I ett första steg sker det genom att staten juridiskt definierar hur den ser på gruppen av kyrkor och samfund.

I Lag (1998: 1593) om trossamfund är det återigen § 2 som anger den viktigaste definitionen: "Med trossamfund avses ... en gemenskap för religiös verksamhet, i vilken det ingår att anordna gudstjänst." Lagstiftaren har fastnat för en substantiell definition av trossamfund: "en gemenskap för ... anordnande av gudstjänst" är det grundläggande kriterium som skiljer trossamfund från icke-trossamfund. Att en substantiell och inte en funktionell definition används är kanske inte oväntat; det kan sägas ligga i juridikens natur. Men att valet skulle falla på 'gemenskap för anordnande av gudstjänst' och inte en specifik form för tro (som i 'tros'-samfund) är inte lika självklart. Man kan också konstatera att lagstiftaren undvikit att ange ett essentiellt kriterium, det vill säga ett kriterium som anger alla trossamfunds gemensamma innehållsliga kärna.

Med stöd av lagen kan ett samfund låta registrera sig hos statsmakten och få ett antal rättigheter och skyldigheter. Som registrerat trossamfund har man skyldighet att hålla statsmakten uppdaterad om vilka personer som leder samfundet, hur de kan nås, och ett antal andra registeruppgifter. Ett registrerat trossamfund får de juridiska rättigheter som följer med en status som rättssubjekt (§ 9), och det förvärvar tillsammans med ett antal andra rättigheter möjlighet att få hjälp från Skatteverket med uppbörden av medlemsavgifter. Hjälpen med ett system för inbetalning av medlemsavgifter är en betydelsefull förmån. Det trossamfund som accepterar denna hjälp knyter an till systemet för skatt till (den sekulära) kommunen, med bevarat avdrags- och progressivitetsmekanik. Det leder i princip till att höginkomsttagare får betala en högre procent av den taxerade inkomsten än låginkomsttagare, det vill säga samma automatik som gäller för uppbörden av Svenska kyrkans medlemsavgifter.

Benägenheten bland trossamfunden att låta registrera sig hos statsmakten varierar. Å ena sidan har inte alla kyrkor och samfund positiva erfarenheter av relationer till statsmakten. En del kyrkor och samfund har en medlemskår som till stora delar flytt från statligt och ibland religiöst förtryck. Tanken på att statsmakten genom Skatteverket får uppgift om individuellt medlemskap i ett trossamfund kan av förståeliga 
skäl framkalla negativa reaktioner. Att enbart se en sådan möjlighet som en administrativ ordning hos en statsmakt som i Sveriges fall sedan mitten av 1850-talet varit ointresserad av invånarnas religiösa preferenser kan innebära ett radikalt nytänkande för migranter med färska erfarenheter av andra staters agerande.

$\AA ̊$ andra sidan finns det grupper utan traditionell religiös profil som kan tänka sig att bli registrerade som trossamfund för att dra nytta av trossamfundens rättigheter. Tillsammans illustrerar dessa ytterligheter det generella problem som 'definition' innebär, på det religiösa området och annorstädes. Gränsdragningsproblematiken, att hitta ett exakt kriterium för 'innanför och utanför', innebär ofta att såväl avsedda som icke-avsedda företeelser hamnar på rätt respektive fel sida om den definitoriska gränsen.

Med lagen om trossamfund, som fråntar Svenska kyrkan merparten av dess särställning bland kyrkor och samfund, öppnas en ny möjlighet till samverkan och solidaritet mellan trossamfund, tydligast manifesterat bland de kristna kyrkorna och samfunden.

\section{Sveriges Kristna Råd}

I egenskap av trossamfund bland andra trossamfund är Svenska kyrkan medlem i ett nytt samarbetsorgan, Sveriges Kristna Råd. Rådet förfogar över ett sekretariat med ett tjugotal anställda. Medlemmar i detta råd är fyra lutherska kyrkor, sex frikyrkor plus en observatör, Romersk-katolska kyrkan, samt fjorton ortodoxa kyrkor. Att majoritetskyrkan Svenska kyrkan velat ha mycket att säga till om i detta organ är uppenbart, men å andra sidan tycks det finnas en vilja att inte låta trossamfundens medlemstal fälla utslaget i rådets diskussioner, beslut och anställningspolicy. En indikator på detta kan vara att en väsentlig andel av rådets sekretariatsanställda har en annan bakgrund än Svenska kyrkan, vilket i huvudsak handlar om de äldre svenska frikyrkorna. Anställda med bakgrund i någon av de ortodoxa kyrkorna är få.

Det har diskuterats om tillkomsten av Sveriges Kristna Råd har inneburit att ett tydligare och samlat kristet ställningstagande, oberoende av statsmaktens linje, har blivit möjligt. Sannolikt förhåller det så. I ett antal frågor (bl.a. migrationsfrågor) har Sveriges Kristna Råd tydligt markerat en annan uppfattning än regeringen och migrationsmyndigheterna. År 2005 samlade rådet i 'Påskuppropet' 157000 namnunderskrifter för en generösare flyktingpolitik, ett upprop som enligt bedömare bidrog till en uppgörelse i riksdagen våren 2006. Den gav många gömda flyktingar en ny möjlighet att få uppehållstillstånd (Svenska kyrkan 2014b). Att Svenska kyrkan var delaktig i en sådan markering skulle knappast ha kunnat förekomma under Svenska kyrkans tid som statskyrka.

Kvarvarande och nya gränssnitt

Det intima sambandet mellan kyrkan och staten med rötter i Gustav Vasas reformation och kyrkopolitik 1524 - ca 1545 (Rodén 2010) löses upp vid millennieskiftet. Som 
visat innebär det nya gränssnittet inte att alla kopplingar försvinner. Några av kopplingarna förvandlas till allmänna bestämmelser som gäller för alla trossamfund, medan andra blir specifika bestämmelser för just Svenska kyrkan.

\section{Vigselrätt}

Vissa kyrkliga handlingar har även efter relationsförändringen civila konsekvenser. Ett äktenskap som ingås i en kyrka är juridiskt giltigt och kan registreras av Skatteverket (den administrativa åtgärd som innebär att det får rättsverkan). Rätten att viga tilldelas också efter relationsförändringen alla de trossamfund som ansöker om det och som motsvarar de statliga kraven. Här inträder inga drastiska förändringar med anledning av att Svenska kyrkan bryts ut ur staten.

Statsmaktens delegation av vigselrätt till trossamfund är emellertid noggrant specificerad och sker i två steg. Först måste trossamfundet godkännas. Det måste i ansökan visa att det har en stabil verksamhet och att dess organisation formår att honorera lagstiftningens bestämmelser om vigsel. Därefter måste en person som trossamfundet rekommenderar godkännas att fungera som vigselförrättare [officiant ved bryllup]. Den statliga myndighet som förvaltar regelverket, Kammarkollegiet, är noga med att inte ange särskilda titlar på de personer som trossamfunden rekommenderar. Godkännande som vigselförrättare är alltså inget som hör ihop med prästvigning eller pastorsavskiljning (de fria kyrkornas motsvarighet till prästvigning). Vilken person som helst - som det godkända trossamfundet rekommenderar och som har de personliga kvalifikationer som Kammarkollegiet specificerat - kan bli vigselförrättare.

Gränssnittet mellan stat och trossamfund ifråga om vigsel är sålunda fastlagt av statsmakten, som centralt via Kammarkollegiet håller hårt i kontrollen. Staten beviljar och staten återkallar beviljande. Om ett trossamfund inte kan eller vill inordna sig under statsmaktens regelverk beviljas ingen vigselrätt. När det gäller borgerlig vigsel är förfarandet mindre stramt. Det saknas för det första en motsvarighet till prövningen av trossamfund. För det andra har en decentralisering skett. Beslut om borgerliga vigselförrättare har delegerats till de regionala statliga förvaltningarna, länsstyrelserna [amterne].

Det är tveksamt om uppfattningarna om vigsel hos svenska folket motsvarar denna stringenta juridiska stramhet. Antagligen är den bild av vigsel som finns hos giftaslystna unga vuxna i Sverige att Svenska kyrkans rätt att viga bygger på en annan legitimering än Kammarkollegiets tillståndsgivning, nämligen en i det kyrkliga ämbetet inneboende kvalitet. Att borgerliga vigselförrättare är godkända i sekulär ordning känner nog unga vuxna till, men att en liknande procedur gäller för präster och pastorer är antagligen okänt. Karin Jarnkvists intervjuer med unga par före och efter deras borgerliga respektive kyrkliga vigsel antyder detta (Jarnkvist 2011). Hos 
dessa unga uppfattas inte gränssnittet mellan trossamfund och stat ifråga om vigsel som entydigt definierat av statsmakten.

\section{Statligt stöd till trossamfund}

Staten uppskattar viktiga delar av trossamfundens verksamhet och stöder verksamheten med bidrag. Enligt Lag om stöd till trossamfund (SFS 1999: 932) avsätts årligen en mindre summa pengar (60 MSEK i 2012) till Nämnden för statligt stöd till trossamfund, som administrerar bidragen. Statsbidrag kan utdelas till trossamfund som “ bidrar till att upprätthålla och stärka de grundläggande värderingar som samhället vilar på” (Lag om stöd till trossamfund § 3). Pengarna används till organisationsbidrag, teologiska högskolor/seminarier, andlig vård inom sjukvården, lokaler, handikappanpassning av lokaler, etablering och utbildning. Svenska kyrkan får inte statsbidrag genom nämnden utan făr sitt ekonomiska stöd genom att staten bekostar dess kyrkoavgiftsuppbörd. Den kostnaden beräknas till ungefär 115 miljoner kronor (Ibid.). För närvarande finns 18 bidragsberättigade kyrkor eller trossamfund och 3 samarbetsråd. Dessa stödformer har funnits långt före relationsförändringen mellan Svenska kyrkan och svenska staten och är sålunda inget som direkt har med relationsförändringen att göra.

\section{Begravningsväsendets outsourcing till Svenska kyrkan}

Begravningsväsendet outsourcas - som nämnts - till Svenska kyrkan. För medlemmar i Svenska kyrkan ingår begravningsavgiften i kyrkoavgiften, men även ickemedlemmar måste betala en begravningsavgift. Avgiften är differentierad (olika församlingar har olika kostnader) och kanaliseras till entreprenadorganisationen, trossamfundet Svenska kyrkan, oberoende av medlemskap. Man kan säga att ordningen innebär ytterligare ett exempel på kvarvarande problematik om negativ religionsfrihet. Avgifter från icke-medlemmar används för att bekosta allmän verksamhet i Svenska kyrkans regi.

\section{Kyrkoantikvarisk ersättning till Svenska kyrkan}

Ett problem vid relationsförändringen är att klargöra vem som äger kyrkobyggnaderna och den mark som de och kyrkogårdarna tar i anspråk. Att kyrkan har dispositionsrätt över byggnaderna är klart, men det blir i förhandlingarnas inledande skede en öppen fråga om också ägarskapet ska tillfalla trossamfundet Svenska kyrkan. Mycket av allmänna medel från medborgarna har använts för att bygga och underhålla kyrkorna, som de facto är landets äldsta byggnadsbestånd. Utöver den religiösa funktionen hos kyrkorna finns därmed en aspekt som har med kulturarv att göra. Kyrkorna hör till det nationella kulturarvet, och det är inte alldeles enkelt att avgöra om staten bör släppa ifrån sig ägarskapet över ett sådant arv.

Endast för en (1) kyrka är ägarförhållandena klara; Lunds domkyrka är en självständig förmögenhet (Skatteverket 2014). För andra kyrkor finns i förhandlingarnas 
utgångsposition ingen lika enkel lösning. Det kommer att utgöra en av förhandlingsfrågorna om det är staten eller den kyrka som tidigare var statens som ska få egendomsrätt till dessa specialbyggnader. Den framförhandlade lösningen blir att trossamfundet får egendomsrätten. Svenska kyrkan kan därmed förfoga över byggnaderna för de religiösa funktionerna, men får samtidigt ett stort problem att hantera. De gamla kyrkohusen behöver ofta stora och kostsamma reparationer och renoveringar. För att i någon mån råda bot på detta införs i Lag (1988:950) om kulturminnen m.m. (ändring t.o.m. SFS 1999: 942) en bestämmelse om att Svenska kyrkan har rätt till kyrkoantikvarisk ersättning (§ 16).

Storleken på den kyrkoantikvariska ersättningen fastläggs inte i lagtexten, utan lämnas att förhandlas mellan kyrkan och staten. Sedan millennieskiftet har ersättningen utvecklats på det sätt som framgår av figur 1.

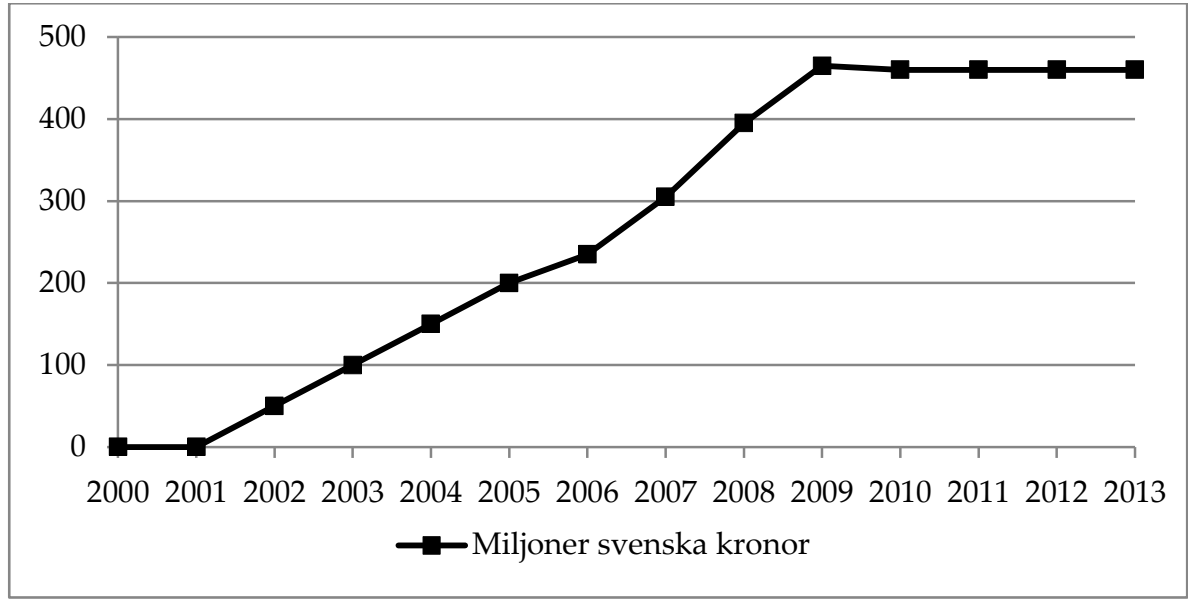

Figur 1: Kyrkoantikvarisk ersättning 2000-2013

Sedan 2009 är beloppet 460 MSEK årligen (Regeringen 2014). Det beloppet har inte indexreglerats, vilket i praktiken innebär at det har urholkats med 5 procent. Att kostnaderna för antikvarisk renovering och reparation inte legat still är sannolikt, så det finns en motsättning och en pågående diskussion mellan regeringen och Svenska kyrkan om storleken på ersättningen.

\section{Oväntade utvecklingar för det fria trossamfundet Svenska kyrkan}

Vad händer när oljetankern, som till slut vänts, seglar vidare? Blir kursen den planerade, och uppför sig farvattnen som väntat? Stämmer de framtidskalkyler som lades fram under skilsmässoprocessen med hur det faktiskt blivit? Har gränssnitten mellan 
svenska samhället, svenska staten och Svenska kyrkan fungerat på det sätt som avsetts?

Man kan konstatera att de protokollerade gränssnitten (t.ex. avgiftsuppbörd och medlemsregister) har fungerat så tillvida att inga störningar blivit föremål för diskussion i nyhetsmedia. Vissa överraskningar har det dock blivit under skilsmässotillståndets fjorton första år. Två sådana överraskningar ska nämnas, medlemsförlust och strukturomvandling.

\section{Medlemsförlust}

Medlemssiffrorna har minskat mer än vad Svenska kyrkan räknat med. 65,9 procent av befolkningen är medlemmar december 2013, en minskning från 82,9 procent vid millennieskiftet, alltså 17 procentenheter (Svenska kyrkan 2014c). En så stor medlemsminskning har stora konsekvenser, både för organisationen, medarbetarnas självkänsla och kyrkans ekonomi. Det uppkommer övertalighet bland kyrkobyggnaderna. Många av dem ligger på 'fel' platser, det vill säga på platser där folkmängden på grund av folkomflyttningen inte längre rättfärdigar en egen kyrkobyggnad. Personalen håller på att bli för talrik. Det måste finnas en följsamhet mellan antalet kyrkligt anställda och kyrkoavgifterna, som är den primära finansieringskällan för personalkostnaderna. En medlemsminskning har konsekvenser för kyrkoavgifterna och därmed för det finansierbara antalet anställda.

\section{Strukturomvandling}

På ytterligare ett område förväntar sig kyrkan att kunna stå still, trots att samhället visar sig röra på sig, nämligen på strukturområdet. Strukturrationaliseringar präglar Sveriges land efter år 2000 (och i någon mån redan tidigare). Små kommuner har sedan länge slagits ihop till större enheter, och län och landsting [amter och amtskommuner] slås ihop till allt större enheter. Den parokialt (geografiskt) organiserade Svenska kyrkan drabbas av två tendenser samtidigt. Den ena tendensen är att många av de små församlingarna blir för små för att kunna bära kostnaderna för t.ex. kyrkounderhåll, vilket pekar i riktning mot sammanslagning till större enheter, främst i avfolkningsbygd. Den andra tendensen finner man i de större städerna, nämligen en insikt om att församlingsindelningen för församlingsborna spelar en allt mindre roll. I staden håller sig inte besökarströmmarna inom församlingsgränserna, utan kyrkobesökarna 'kyrk-shoppar' fritt. Därmed blir de rimligt att också kyrkoorganisationen lägger mindre vikt vid gamla församlingsgränser. Dessutom växer insikten om att många parallella församlingar och pastorat i samma stad innebär mycket dubbelarbete. Ett antal större städers många församlingar samlas därför i ett enda stadspastorat under en kyrkoherde (Från 2014-01-01 Västerås, Uppsala och Örebro, Gävle m.fl. städer). Resultatet blir att antalet pastorat (och kyrkoherdar) minskar kraftigt. 
I rask takt håller sålunda den kyrkliga kartan på att ritas om. Framförallt sker detta genom ändringar av församlingsgränserna. Små församlingar med minskande befolkningar - framförallt på landsbygden - slås ihop till större enheter. I tabell 1 visas i bearbetad form Statistiska centralbyråns sammanfattning av församlingar som på olika sätt tagits 'ur drift' under perioden från millennieskiftet och fram till 2014-01-01 (Statistik Centralbyrån 2014).

\begin{tabular}{|l|r|}
\hline Tabell 1: Församlingssammanslagningar 2000 - & \\
2014 & Antal församlingar \\
Ändringstyper & 171 \\
\hline Upphör till befintlig & 62 \\
\hline Utvidgad, ej namnändrad & 240 \\
\hline Utvidgad och namnändrad & 2 \\
\hline Minskad, ej namnändrad & 0 \\
\hline Minskad och namnändrad & 261 \\
\hline Namnändrad ej kodändrad & 763 \\
\hline Berörda församlingar & \\
\hline
\end{tabular}

Som anfört ovan ska Svenska kyrkan enligt lag vara rikstäckande. Alltså kan ingen församling försvinna och lämna kvar en vit fläck på kartan. De stora antalen i tabell 1 handlar därför om församlingar som utvidgats (det vill säga som har 'uppslukat' andra församlingar), församlingar som har upphört (det vill säga blivit 'uppslukade' av en annan församling) och församlingar som fått nytt namn (som följd av sammanslagning).

Förändringarna genomförs i huvudsak vart fjärde år, eftersom de anpassas till den demokratiska styrformen, det vill säga valen till de kyrkliga beslutsorganen. Omfattningen av strukturomvandlingen på församlingsnivå åskådliggörs i figur 2. 


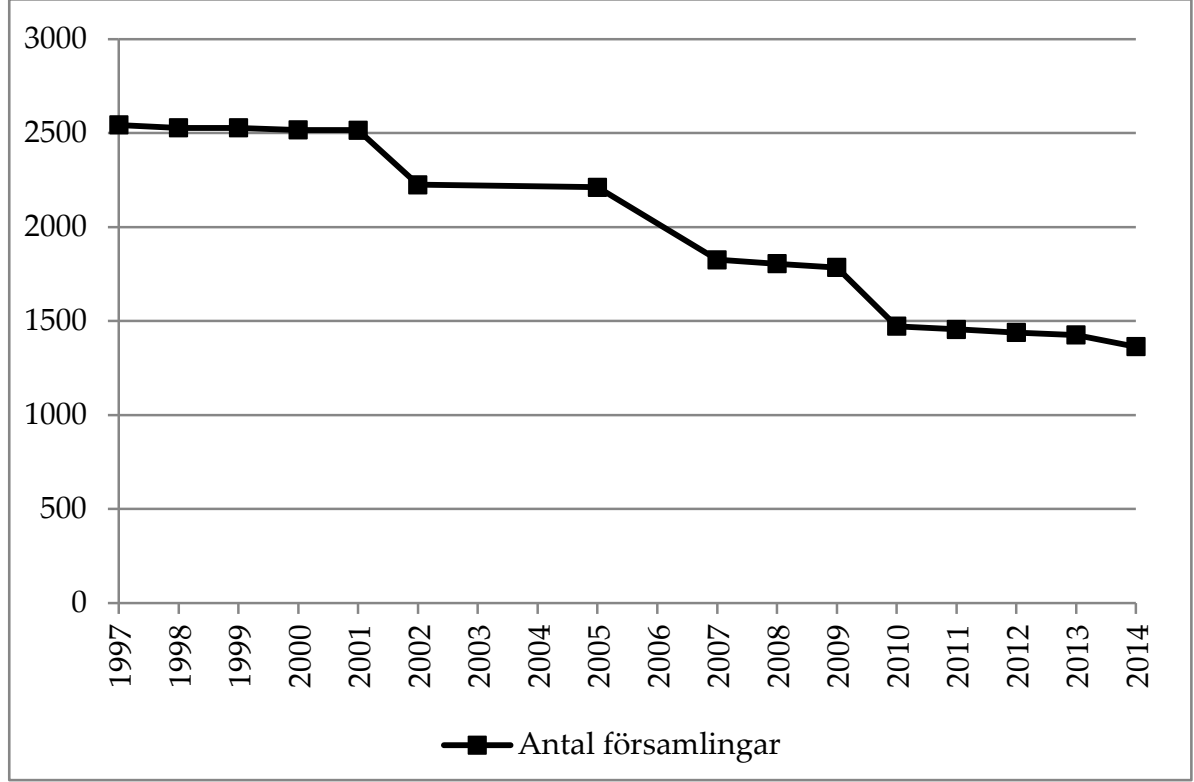

Figur 2: Antal församlingar 1997-2013

De administrativa och pastorala enheterna har blivit större till ytan, i de större städernas fall också till antalet kyrkomedlemmar. Och de har blivit färre. Från en nivå runt 2500 församlingar vid millennieskiftet har antalet minskat till 1364 fjorton år senare (Sverigesradio 2014; Statistisk centralbyrån 2000). Att en omstrukturering av denna omfattning tar mycket kraft är givet. Man kan fundera på om denna kraft hade behövts i andra kyrkliga angelägenheter. Uttryck för en sådan tanke kan man finna hos Straarup \& Ekberg (2012).

\section{Konklusion med "eftertankens kranka blekhet"}

Mer än ett decennium efter att ordningen trätt i kraft, kan man säga att skilsmässan mellan kyrkan och staten har satt sig. Svenska kyrkans medarbetare har vant sig vid tanken att de inte, den mån de eventuellt gjort det tidigare, representerar staten, utan i stället en evangelisk-luthersk kyrka med en fyrasidig uppgift: gudstjänstfirande, diakoni, undervisning och mission. Den kyrkliga organisationen vågar ta beslut som inte är följsamma med statsmaktens önskemål, och statsmakten bedömer sitt engagemang i kyrkliga ärenden på ett sätt som är parallellt med engagemanget när det gäller statens övriga åtaganden och uppdragstagare. Medlemsminskning och en snabb rationalisering av det parokiala systemet har överraskat Svenska kyrkan, men om ambitionen att innehållsligt vara samma kyrka före och efter millennieskiftet får sägas ha genomförts framgångsrikt, finns det två andra avseenden i vilka Sverige 
befolkning har svårighet att känna igen kyrkan. För det första har det faktum att medlemsandelen minskar fått en dominerande plats i det offentliga samtalet om Svenska kyrkan; för Sveriges befolkning framstår kyrkan inte längre som ett autentiskt uttryck för svenskhet. En organisation med enbart två tredjedelar av befolkningen som medlemmar är inte representant för helheten. För det andra är förändringarna i den geografiska, parokiala, indelningen en känslig fråga för dem som söker sig till kyrkans verksamhet. Vad som för organisationskonsulter och anställda ter sig som en 'naturlig' utveckling rimmar illa med personlig upplevelse av identitet och tillhörighet. För enskilda individer med anknytning till Svenska kyrkan är tillhörigheten till en specifik församling, dess byggnader och personal, av stor vikt

För Sveriges befolkning är de stora kyrkliga förändringarna under det tredje millenniets fjorton första år inte i första hand skiljandet av kyrkan från staten, utan sådana befolknings- och samhällsförändringar som - förmodligen - skulle ha infunnit sig även om inte Svenska kyrkan skiljts från svenska staten.

Ett liknande system - som inte har nämnts ovan - är Svenska kyrkans medlemsregister. Trossamfundet för inget eget register. I stället är uppgiften om medlemskap en delmängd i det allmänna folkregistret. För att ett antal hänsyn kan bli tillgodosedda krävs noggrant specificerade protokoll - eller gränssnitt - för vilka typer av anställda som får göra vad med vilka registerdata. Lagstiftningens och statsmaktens krav om identitets- och integritetsskydd för befolkningen måste förenas med Svenska kyrkans krav på information om sina medlemmar och kyrkans behov av att på personnivå lagra uppgifter som t.ex. dop- och konfirmationsdag.

Gränssnitten mellan staten, Svenska kyrkan, andra trossamfund och religiösa organisationer har ändrats på en rad områden som följd av separationen mellan kyrka och stat år 2000. Dessa relationsförändringar kan iakttas utifrån ett operationellt, juridiskt perspektiv, men 'skilsmässan' mellan kyrka och stat pekar också fram emot et annat och mer tentativt bruk av gränssnittsbegreppet. Historiskt har en nära relation mellan stat och kyrka lett till att förbindelsen mellan de båda också har karaktär av 'mötesplats'. De båda har mångfasetterade relationer. I somliga lägen finns det lagar och bestämmelser som reglerar de ömsesidiga uppgifterna, i andra har ingen reglering visat sig nödvändig. I detta 'fria' område finns inga protokoll som specificerar vad var och en ska göra, utan här har inspiration, politik och - som i det här analyserade avseendet - teologi ett rådrum.

\section{LITTERATUR}

1968 års beredning om stat och kyrka

1972 Samhälle och trossamfund: slutbetänkande, Statens offentliga utredningar 36, Beckman, Stockholm.

Eckerdal, Per

2009 Arbetsformer i förändring - församlingens uppgift och förutsättningar, Svenska kyrkans utredningar 2, Kyrkokansliet, Uppsala. 
Edqvist, Gunnar

2000 Från kyrkolag till kyrkoordning, Verbum, Stockholm

Edqvist, Gunnar et al.,

1996 Svenska kyrkan i förnyad gestalt: 1995 års beslut om kyrka och stat, Verbum, Stockholm.

ERK-utredningen

1992 Ekonomi och rätt $i$ kyrkan: slutbetänkande, Statens offentliga utredningar 9, Allmänna förlaget, Stockholm.

Jarnkvist, Karin

2011 När jag gifter mig ska jag göra det på riktigt: berättelser om barn, brudar och bröllop, Institutionen för idéoch samhällsstudier, Umeå universitet, Umeå.

Kyrkomöte

1999 Kyrkoordning för Svenska kyrkan: fastställd av Kyrkomötet 1999, Verbum, Stockholm.

2000 Kyrkoordning med angränsande lagstiftning för Svenska kyrkan, Verbum, Stockholm.

Rodén, Marie-Louise

2010 "Reform eller revolution? Ett kyrkligt uppror som förändrade Europa", in: Dick Harrison \& Bo Eriksson, eds., Sveriges historia: 1350-1600, Norstedt, Stockholm, 477-492.

Roth, Hans Ingvar

2012 Är religion en mänsklig rättighet?, Norstedt, Stockholm.

Statistiska centralbyrån

2000 Rikets indelningar 2000: årsbok över regionala indelningar med koder, postadresser, telefonnummer m. m., Statistiska centralbyrån, Stockholm.

Straarup, Jørgen

1996 "Kyrka och folk i dag och i nya relationer - ett religionssociologiskt perspektiv", in: Gunnar Edqvist et al., Svenska kyrkan i förnyad gestalt: 1995 års beslut om kyrka och stat, Verbum, Stockholm, 49-62.

Straarup, Jørgen \& Mayvor Ekberg

2012 Den sorglöst försumliga kyrkan. Belyst norrifrån, Artos \& Norma bokförlag, Skellefteå.

Svenska kyrkan

2012 Nyckeln till Svenska kyrkan - en skrift om organisation, verksamhet och ekonomi 2012, Kyrkokansliet, Uppsala.

Lagtexter

Lag (1998: 1591) om Svenska kyrkan.

Lag (1998: 1593) om trossamfund.

Lag om stöd till trossamfund (SFS 1999, 932).

Lag (1988: 950) om kulturminnen m.m. (ändring t o m. SFS 1999, 942).

Begravningslag (1990: 1144) med ändringar t o m SFS 1999, 1268.

\section{INTERNETSIDER}

"Regeringen 2014"

regeringen.se/sb/d/15296/a/181094 (sett 2014-04-25).

"Skatteverket 2014"

skatteverket.se/rattsligvagledning/1738.html (sett 2014-04-25).

"Statistiska centralbyrån 2014"

scb.se/Grupp/Hitta_statistik/.../Pastandr2014_0624.xls (sett 2014-04-25).

"Svenska kyrkan 2014a"

svenskakyrkan.se/statistik (sett 2014-04-25).

"Svenska kyrkan 2014b"

svenskakyrkan.se/migration (sett 2014-04-25).

"Svenska kyrkan 2014c"

svenskakyrkan.se/default.aspx?id=1107096 (sett 2014-08-28). 
"Sveriges Kristna Råd 2014"

skr.org (sett 2014-04-25).

"Sveriges Radio 2014"

sverigesradio.se/sida/artikel.aspx?programid=83\&artikel=5748769, svenskakyrkan.se/statistik, och scb.se/sv」Hitta-statistik/Statistik-efter-amne/Befolkning/Befolkningenssammansattning/Befolkningsstatistik/25788/25795/ (sett 2014-04-25).

Jørgen Straarup, professor

Södertörns högskola, Sverige 

